\title{
Kültürlerarası iletişim olgusunun sinema boyutu: Makedon sineması
}

\section{Sibel AKOVA 1} APA: Akova, S. (2020). Kültürlerarası iletissim olgusunun sinema boyutu: Makedon sineması.
RumeliDE Dil ve Edebiyat Araşttrmaları Dergisi, (18), 335-349. DOI: 10.2900o/rumelide.705708

\section{$\ddot{O} \mathbf{z}$}

"İnsanlık için, aydınlık için, gelecek için sinema yapıyoruz, filmlerimiz insanlık mücadelesi içindir, kriterlerimiz yoktur” özdeyişi ile Josef Broz Tito’nun, nefesi ile üfleyerek can kattığ ${ }^{2}{ }^{2}$ kristal ülke olarak tariflenen, temelinde Eski Yugoslavya'da, çalışmamızın da konusunu oluşturan Makedonya Sineması, Slav halkının gönüllü desteği, Özyönetim sisteminin varlığı, Sosyal Devlet olma bilinci ve dönemin Tito hükümetinin teşvikleri ile güçlü temeller üzerine inşa edilmiştir. Sinema disiplinine ve sanatına büyük bir özveri ve saygı ile yaklaşan, kıymet atfeden Yugoslav (Güney Slav) halkı, bilimin, güzel sanatların, teknolojinin her alanını destekleyen hükümet liderlerinin, kamu arazilerinin sinema platolarına tahsis edilmesi, dönemin şartları içerisinde önemli miktarda bütçeler ayrılması, bilim, sanat, edebiyat gibi disiplin emekçilerinin eğitimleri adına yurtdışına gidiş imkanlarının tanınması gibi konulardaki destekleri, Makedon sinemasının nicelik ve nitelik anlamda gelişiminin başat unsurlarını oluşturmuştur. Tarihi 1905'li yıllara dayanan, Milton ve Yanaki Manaki Kardeşler'in ilk yaşayan (canlı) görüntüleri Bioscope adlı kameraya almaları ile başlayan Makedon Sineması, 1952 yılında Vardar (Skopje/Üsküp) Film Stüdyosu'nun kurulması ile birlikte, özgün, yaratıcı ve kaliteli yapıtlara imza atarak, önemli başarılar elde ederek, isminden söz ettirmiştir. Jeostratejik konumu itibariyle, savaşların ve beraberinde travmaların sıkça yaşandı̆̆ı, temelde Balkan Coğrafyasında ve dahi Makedon topraklarında süregelen güncel olayların, Makedon Sineması'na da yansıdı̆̆ını ifade etmek mümkündür. Manaki kardeşlerin sinema sanatının ilk tohumlarını attığı Balkan toprakları Üsküp’te (Skopje) Vardar (Makedonya), Saraybosna'da (Sarajevo) Sutjeska (Bosna Hersek), Budva'da Zeta (Karadağ), Zagreb'de Jadran (Hırvatistan), Belgrad'dan Avala (Surbistan) ve Ljubljana'da Triglay (Slovenya) devlet destekli kurulan film kasabalarının yapitları ile önemli başarılar elde etmişlerdir. İlgili film kasabaları Balkan coğrafyası sinema sanatına önemli katkılar sağlar iken bir yandan Josip Broz Tito'nun da etkisi ile yoğun düzeyde propaganda aracı olarak kullanılabilmiş öte yandan da dönemin şartları içerisinde farklı coğrafyalara film ihraç edebilme ve ülke ekonomisinde lokomotif bir sektör olma başarısını kazanmıştır. Özellikle Vardar Film platosunun gelişim süreci araştırmanın sorunsalını oluşturmaktadır.

Anahtar kelimeler: Makedon sinemasi, Balkan, Yugoslavya, Vardar Film, Manaki Kardeşler.

1 Dr. Öğr. Üyesi, Yalova Üniversitesi, Sanat ve Tasarım Fakültesi, İletişim Sanatları Bölümü, İletişim Sanatları ABD (Yalova, Türkiye), sibelakova@gmail.com, ORCID ID: 000o-0001-7680-7394 [Makale kayıt tarihi: 28.12.2019-kabul tarihi: 20.03.2020; DOI: 10.29000/rumelide.705708]

Yugoslavya ülkesinin kuruluş süreci, Eski Yugoslavya halkı tarafından Josef Broz Tito’nun, nefesi ile üfleyerek can kattı̆̆ kristal bir ülke olarak betimlenmektedir. Farklı etnik kökenlere mensup halkların Güney (Yugo) Slavları üst kimliğinde bir araya geldiği Yugoslavya ülkesi, Tito döneminde birlikte (ortak) yaşam kültürünü deneyimlemişlerdir. Tito’nun ölümü sonrası etnik çatışmalar sonucunda parçalanan Yugoslavya'nın Balkanizm olarak adlandırılan bölünme süreci ise Josef Broz Tito’nun, nefesi ile üfleyerek can kattığı kristalin kırılması olarak ifade edilmektedir. 


\title{
Cultural transmission in Macedonian Cinema in the context of intercultural communication
}

\begin{abstract}
Defined as crystal country into which Josef Broz Tito breathes life from his soul with his motto "We are filming for the humanity, for the enlightment, for the future; our films are for the humanity struggle, we have no criteria ", at the heart of the former Yugoslavia and the subject of our study, Macedonian Cinema was built on was built on strong bases with the voluntary support of the Slavic people, the existence of the self-government system, the consciousness of becoming a Social State, and the incentives of Tito government of the period. The supports of government leaders encouraging all fields of technology, fine arts and science at some issues such as allocation of public lands to cinema platforms, substantial budget allocation under the conditions of the period, recognition of travel opportunities abroad for the training of disciplinary laborers such as science, art, literature and the people of Yugoslavia (Southern Slav) approaching the cinema discipline and art with great dedication and respect constituted the dominant elements of the quantitative and qualitative development of Macedonian cinema. Dating back 1905 and starting with videotaping of first living thing's images with the camera called Bioscope by Milton and Yanaki Brothers, Macedonian Cinema, with the establishment of the the Vardar (Skopje) Film Studio in 1952, put its signature under important successes, had its name rather frequently mentioned and succeeded with original, creative and quality works. In terms of geostrategic position, it can be said that wars and traumas accompanied by them frequently, current events ongoing essentially in Balkan Geography and Macedon lands are reflected in Macedonian cinema. In the Balkans, Manaki brothers sow the seeds of cinema. They achieved significant success in Skopje Vardar (Macedonia), in Sarajevo Sutjeska (Bosnia-Herzegovina), in Budva Zeta (Montenegro), in Zagreb Jadran (Croatia), in Belgrade Avala (Serbia), in Ljubljana Tirglay (Slovenia) with works of movie towns which were supported by the government. Those movie towns made a big contribution to Balkan region's cinema industry, in addition to that, movies were heavily used as propagandistic materials, with Josip Broz Tito's help. At the same time, the industry grew so much that they started exporting movies and it became a locomotive sector in the economy. Specifically, the development of Vardar Movies is the pain point of this research.
\end{abstract}

Keywords: Macedonian cinema, Balkan, Yugoslavia, Vardar Film, Manaki Brothers.

\section{Giriş}

Günümüzün Yunanistan toprakları yakınında yer alan Greneva kenti yakında Avdella köyünde dünyaya gelen Milton Manaki (1880-1064) ve Yanaki Manaki (1878-1954) kardeşler, dönemin kültür yapısına koşut şekilde yaşamlarını idame ettiren, beş çocuklu çiftçi bir Ulah (Makedon Rumeni) ailenin evlatlarıdır. Lumiere kardeşlerin sinema sanatını insanlık tarihine kazandırmalarının yaklaşık on yıl sonrasında, tarihsel mizansen dahilinde Osmanlı İmparatorluğu'nun Balkan topraklarında hüküm sürdüğü süreç içerisinde, günümüzün Makedon Sineması'nın öncüleri olarak addedilen Milton ve Yanaki Kardeşler, Balkan sinema sanatının (Sinematografya) gelişiminde olduğu kadar Osmanlı tebaası olmaları sebebi ile günümüz Türk sinemasının da gelişimi konusunda başat rol üstlenmişlerdir.

II. Dünya Savaşı sırasında ve özellikle milli kimlik bilincinin oluşturulması çabasını güden devletler, iktidarları vasıtası ile propagandalarını halkın her bir kesimine duyurabilmek adına sanat dallarının 
hemen her bir alanını kullanma ihtiyacı hissetmişlerdir. Sinema sanatı da yaygınlığı, empoze edilmesi istenen düşünceyi, sistemi ve yapıyı sayısız farklı şekilde aktarabilme olasılığı ile toplumu baskı altına almadan ikna temelli özelliği sebebi ile iktidarlar tarafından en çok tercih edilen sanat disiplini olarak addedilmektedir. Yugoslavya Sosyalist Federal Cumhuriyeti (YSFC) de kurulduğu dönem itibariyle, Güney Slav (Yugo Slav) halklarına milli kimlik bilinci düsturunun aşllanması konusunda sinema sanatını en etkin şekilde kullanan devletlerden biri olarak literatürdeki yerini almıştır. Josep Broz Tito'nun iktidara geldiği günden ölümüne değin iktidarda kaldığı süreçte, Yugoslavya topraklarında sinema sanatının gelişimi adına dönemin şartları içerisinde eşi benzeri görülmemiş şekilde desteklenmesini sağlamıştır. Çok kimlikli, çok etnili (etnik kökenli), çok kültürlü, çok dilli, çok dinli ve çok milletli olarak addedilen Yugoslavya topraklarında yaşayan, Boşnakları, Sırpları, Hırvatları, Karadağlıları, Slovenlerı, Arnavutları, Balkan Yahudilerini, Balkan Çingenelerini, Ulahları ve Türkleri, dünya üzerindeki etnik çeşitliliğin üst düzeyde yer aldığı milletleri, Yugoslav üst kimliğinde birleştirmeyi başarabilmiş olan Yugoslavya Sosyalist Federal Cumhuriyeti'nin (YSFC) kurucusu Josep Broz Tito, etnik çeşitliliğin, birlikte yaşam kültürünün aşılanması ile zenginliğe çevrilebileceği düşüncesine inanmış ve inancı doğrultusunda çalışmaları yürütmüştür.

Çok etnili yapıyı, eşit ve adil haklar mottosunu ilke edinerek, bir araya getiren ve birlikte yaşam pratiklerinin en uygun şekli ile tesis edilmesini sağlayan Tito, Kardeşlik ve Birlik (Bratstvo i Jedinstvo Brotherhood and Unity) söylemi ile hareket etmiştir. Dünyanın en önemli etnik laboratuvarı olarak addedilen Balkan milletlerini, Milton ve Yanaki Manaki kardeşlerin yaktığı sinema ateşinin coşkusunun azalmasına izin vermeden, Yugoslavya topraklarında yedi farklı bölgede sinema platolarının kurulmasını destekleyerek, devlet bütçelerini tahsis ederek, sinema emekçilerinin yetiştirilmesi adına azımsanamayacak nitelikte katkılar sağlayarak, bir yandan Balkan topraklarında sinema sanatının gelişimini desteklerken öte yandan da sinema disiplinini farklı etnik kökenlere mensup Balkan toplumlarını Yugoslav üst kimliğinin benimsenmesi konusunda propaganda aracı olarak kullanan Josip Broz Tito, günümüzde dahi Makedon sineması başta olmak üzere, Balkan sinemasının gelişimi adına en önemli katkıları sağlayan lider olarak addedilmektedir. Belgrad'da kurulan Avala (Sirbistan), Saraybosna'da kurulan (Sarajevo) Sutjeska (Bosna Hersek), Zagreb'de kurulan Jadran (Hırvatistan), Budva'da kurulan Zeta (Karadağ-Crna Gora-Montenegro), Ljubljana'da kurulan Triglay (Slovenya) ve Üsküp'te kurulan (Skopje) Vardar (Makedonya) film stüdyoları, Manaki Kardeşlerin kıvılcımları ile Balkan topraklarında doğan sinema sanatının Yugoslavya Sosyalist Federal Cumhuriyeti'nde gelişiminde öncü rol oynayan sinema kasabalarıdır. Yugoslav hükümetinin katkıları ve halkının destekleri ile unutulmaz nitelikte filmler üreten Makedon ve Balkan sineması, dünya sinema tarihi içerisinde önemli bir yer edinmişlerdir.

Sinema disiplini Makedonya topraklarının kaderine koşut bir gelişim sürecini konu edinmiştir. etüt etmiştir. Huzurlu, istikrarlı, güvenli ve barış içerisinde süregelen dönemler, Makedon sinema sanatının doğumuna, gelişimine ve başarılarına tanıklık etmiştir. İşgaller, savaşların, etnik huzursuzlukların ve istikrarsız yapıların hüküm sürdüğü dönemlerde ise Makedon sineması duraklamış, gerilemiş ve ivme kaydedememiştir. Balkan coğrafyasının tanıklık ettiği siyasi, ekonomik, sosyal, kültürel ve teknolojik değişimler, Makedon sinemasını da aynı ölçütlerde etkilemiş ve dönüştürmüştür. Makedon sinemasının başarısı, gücü, ivmesi, etki alanı, değişimi ve gelişimi her dönem farklllıklara göre kategorize edilse de halkının desteğini hiçbir durumda yitirmemiştir. Antropoloji müzesi olarak nitelenen temelde Balkanlar örneklem düzeyinde Makedonya topraklarında, halkın desteği ve mevcut hükümetlerin teşvikleri oranında gelişim gösteren Makedon sineması, Makedon halkının sinema çalışmalarına dahil edildiği ve halka daima yakın bir yapı sergilemiştir. Makedon halkı, sinemasının gelişimi adına Vardar film 
platosunun tesis edilmesi sırasında olduğu gibi beden gücünden manevi desteğe, maddi anlamda bağış yollu finansal destekten gönüllü sinema emekçiliğine değin pek çok düzeyde katkılar sağlamışlardır.

Makedon sineması abartılı, otantik ve karmaşık temalardan ziyade, gerçekçi, doğal, detaylı ve eleştirel bakış açılarını salık vermektedir. Özellikle 1952 yılı itibariyle, kısa ve uzun metrajlı filmlerin ortak yapımlar ile zenginleştirilmesi Makedon sinemasının yükselişe geçmesini sağlamıştır. Makedon sinemasının yükselişe geçişinde şüphesiz ki sinema emekçilerinin ve sanatçılarının kayda değer payları mevcuttur. Ancak, 1950-1980 yılları arasında, mevcut Josep Broz Tito hükümetinin kültürel, siyasi, ekonomik, teknolojik ve sosyal gelişimlere duyarlılık göstermeleri ve ilgili gelişmeler hususunda devlet desteğinin en üst düzeyde sağlanması yönünde benimsedikleri politikanın katkılarını da göz ardı etmemek gereklidir. Zira, 1956 yllına değin Yugoslavya hükümetinin sağladığı açık destek, Makedon sinemasının gelişimi adına katalizör olma görevini üstlenmiştir. 1956 yılında yürürlüğe giren Yugoslavya Sinema Yasası devletin, sinema sanatına resmi olarak ayırdığı fon ve desteklerin kesilmesi olarak anlamlandırılsa da film üretiminin, gösteriminin ve sektör haline gelen sinema sanatının kesintiye uğramaması adına, sinema biletlerinden devlet adına tahsis edilen \%17 ila \%20 oranındaki vergilerden muaf tutulması kararı, sinema sektörüne addedilen kıymetin de ölçüsünü ifade etmektedir. Ayrıca, devlet fonlarının kesilmesi bir anlamda da Makedon sineması üzerinde hissedilen, devletin gölgesinin kısalması anlamına da gelmektedir. Açı desteğin devlet kararı ile geri çekilmesi, Makedon sinemasının özgür ve özgün yapıtlarının sayılarının da artması ile sonuçlanmıştır. Bă̆ımsız sinema emekçilerinin yapıtlarının nitelik ve niceliği 1956 yllı sonrasında artan bir ivme kaydetmiştir.

\section{Milton Manaki ve Yanaki Manaki Kardeşler ve Bioscope}

Doğu ve Batı kültürünün harman olduğu Makedonya topraklarında 1890 yllında ilk gazetenin yayınlanması ve 1905 yllında ilk tiyatro binasının inşa edilmesi ve dahi resim sanatının gelişim göstermesi, Makedon sinematografisi (Cinématographe) adına kilometre taşı niteliğini haiz gelişmeler olmuştur. Milton ve Yanaki Manaki kardeşler, "Birlikte çalışmaya başladıkları 1898 yılı itibariyle", (Manaki Braća, Filmski Programi Arhiva, Manaki Kardeşler Film Arşivleri, 2004), 2477,2 metre hareketli görüntüden ve 17.583 fotoğraftan oluşan, "1955 yllında Yugoslavya Devlet Arşivleri’ne teslim edilen” (Vidovdan, 2018), ve dahi günümüzde Makedonya Kinematik ve Cumhuriyeti Devlet Arşivleri Manastır (Bitola) Şubesi tarafından koruma altında tutulan, zengin bir koleksiyona isimlerini yazdırmışlardır.

Büyük ağabey Yanaki Manaki, doğum yeri olan Avdela kentinde orta öğrenimini Romen ortaokulunda, lise öğrenimini ise Manastır şehrinde yine Romen lisesinde tamamlamıştır. 1898 yılında Janjina (Yanya) Lisesi'ne, resim öğretmeni olarak göreve başlamıştır. Küçük kardeş Milton Manaki ise akademik anlamda tercihinde Yanakinin aksine Avdela kentinde mevcut olan ortaokulu tamamlamak ile yetinmiştir. Akademik yaşamına devam etmek istemeyen Milton, babaları Dimitri tarafından, zanaat öğrenmek amacı ile ağabeyinin yanına Janjina'ya gönderilmiştir. Manaki Kardeşler’in ilk fotoğraf atölyesi 1898 yılında Yanaki Milton tarafından, Yunanistan'ın Janjina (Yanya/Ioannina) kentinde kurulmuştur.

Yanaki fotoğraf atölyesindeki çalışmalarını, Janjina (Yanya) Lisesi’ndeki öğretmenlik görevine koşut olarak yürütmüştür. Aynı yıl Milton'un da katılımı ile fotoğraf atölyesinde 1904 yılına değin iş birliği içerisinde çalışmalarını yürütmüşlerdir. Janija yakınlarında yer alan “41 yerleşim yerini gezen” (Old Makedonskosonce, 1999), Milton, Rum Patrik Kilisesi temelli yürütülen Yunan propaganda çalışmaları sonucu yaşanan tatsız olaylardan ve çıkan çatışmalardan etkilenerek, Janija Lisesi’nde yürüttüğü 
öğretmenlik mesleğinden ayrılmak durumunda kalmıştır. Öğretmenlik mesleğinden ayrılmasının hemen ardından çalışma izninin de iptal olması ile 1904 yılında ziyaret ettikleri ve diplomatlar (konsoloslar) şehri olarak anılan Manastır (Bitola) kentine, ziyaretlerinin bir yıl sonrasında (1905) “Ṭirok (Şirok) Sokak’ta, Atelje Za Umetničku Fotografiji” (Fotoğraf Sanatları Atölyesi) (Roberta Januloskog, 2018), isimli Türk ve Rum toplumları arasında ünlerinin kısa süre içerisinde yayılacağı, yeni fotoğraf stüdyolarını kurmuşlardır.

Manastır (Bitola) kenti, dönemin şartları içerisinde de günümüzde olduğu gibi Balkan coğrafyasının etnik yapısının izdüşümü niteliğini taşımaktadır. Manastır şehri, Makedonya'nın sosyal, kültürel, sanatsal, ekonomik, siyasi ve idari yapılarının merkezi olma özelliğini taşıyan, jeopolitik konumu itibariyle en önemli kentlerinden biridir. Doğal güzelliklerinden ticaret yolları üzerinde yer edinen konumuna, bereketli topraklarından modern kent (dönemin şartları göz önünde bulundurulduğunda) yapılarına, gelişmiş endüstriyel yapısından elverişli ulaşım imkanlarına, zengin tüccarları ve gelişkin çarşıları itibariyle ticari yapısından idari merkezlerinin çeşitliliğine (diplomatik merkezler ve idari ile yabancı temsilcilikler), üç büyük dinin cami, sinagog, kilise olmak üzere yapılarının buluşmasından sanat ve kültür merkezlerinin varlığına değin farklı etnik kökenlerin, farklı kültürlerin ve farklı inançların birlikte (ortak) yaşam kültürünü etüt ettikleri Manastır şehri, kozmopolit bir kent olma özelliğini uhdesinde barındırmaktadır.

İnanç, dil, milliyet (etnik köken) ve kültür zenginliği öğelerinin varlığı ile birlikte, farklılıkların birlikteliği düsturu ile yaşayan Makedon milletlerinin kültürlerarası iletişim bağlamında dönemin pek çok coğrafyasına nazaran kendine özgü kültürel değerleri oluşturma ve kent olma bilincini taşıma niteliği, Manastır'ın yaşam merkezi olarak addedilmesini sağlamıştır. Elverişli bir yaşam merkezi olma niteliğini haiz olan Manastır, pek çok farklı zümrenin de ilgi odağı olmuştur. Diplomatik ile idari ve yabancı temsilciliklerin yoğunluğu sebebi ile diplomatların ağırlıklı olarak ikamet yeri olarak tercih ettikleri, coğrafi konumu, ulaşım konusundaki elverişli şartları ve dolayısı ile ekonomik gelişmişliği sebepleri ile seçkin zümrenin yerleşim alanı olarak seçtikleri, tabiat güzellikleri ve inanç merkezlerinin ağırlığı sebepleri ile de mutena yüzlerin varlık gösterdiği Manastır şehri, kültür ve sanat akımlarının, moda tarzlarının, tutum ve davranış öğelerinin, sosyal yaşamın ve dahi günlük yaşam pratiklerinin belirlendiği ve Balkan coğrafyası genelinde örnek alındı̆̆ı bir kent olma özelliğini taşımaktadır.

Temelde Makedonya, özelinde Manastır şehri, tarihsel geçmişinden kaynaklanan izleri itibariyle de dönemin şartları içerisinde zengin kütüphanelerinin varlığı, bilim adamlarının etkin çalışmaları, Doğu ve Avrupa kültürlerinin aynı potada eritilme durumunun hakikati ile sanat ve kültürel faaliyetlerin çeşitliliği başta olmak üzere pek çok alanda öncü olma durumunu tatbik etmiştir. Seyyahların, keşişlerin, propaganda görevini üstlenen kişi, kurum ve türevlerinin varllğg da Manastır şehrinin istihbarat merkezleri, otorite kurma ve çıkar sağlama çabası güden zümreler ile siyasi tahrik unsurlarının da odak noktası olarak addedilmesini sağlamıştır. 19. yüzyılın ikinci yarısında kitap, gazete ve dergi gibi mecmuaların yayınlandığı, bilim alanında gelişmelerin yaşandığı, edebiyat alanında ilginin arttığı, orkestra ve koroların resepsiyon ve balolar ile desteklendiği müzik aktivitelerinin çeşitlendiği, resim sanatının geleneğe dönüştüğü, tiyatro sanatının kültür varlıkları içerisinde yer edindiği kültür şehri Manastır, karmaşık yapıların varlığı kadar birey ve topluma dair aktivitelerin zenginliği ile de isminden söz ettiren bir kent olma niteliği taşımaktadır.

“Şehrin kültür hayatında 1895'de Paris'teki sunumundan kısa bir süre sonra Manastır'a gelen sinemanın özel bir yeri vardır. Manastır sakinleri, 1887 'de kimlikleri belirsiz bir İtalyan çiftin, şehre Draç ve Korca üzerinden geldikten sonra, Fransız üretimi filmleri gösterime sokmalarıla ilk hareketli fotoğrafları 
görme şansına sahip olmuşlardır. XX. yüzyılın başlarında da Manastır uzun zaman film kültürünün yayılmasına ve sinema gösterimi faaliyetlerinin gelişmesine öncülük etmiştir. 1906 yılında "Shark" otelinde İtalyan Pietro Chinezi'nin gezici tiyatrosu film gösterimlerini gerçekleştirir." (Stardelov, 2014: 40). Kültürel, sanatsal, siyasi, sosyal ve türevleri pek çok alanda hareketli bir kent yapısı sergileyen Manastır şehri, farklı Avrupa kentlerinde yaşanan gelişme ve etkinliklerden haberdar olma adına da önemli bir görev üstlenmektedir. Manaki Kardeşlerin Manastır şehrine taşınmalarının bir yıl sonrasında, Bükreş’te Dünya Sergisi'ne katılmaları ve eriştikleri ödüller, Roman Kraliyet Ailesi'nin Saray Fotoğrafçısı olmaları yolunda kaderlerini değiştirerek, ünlenmelerini de sağlamıştır. Saray fotoğrafçılığı unvanları Osmanlı ve Sırp İmparatorlukları nezdinde de taçlanmıştır.

Kazandıkları ödüller ve unvanlar farklı coğrafyalara seyahat etme imkanlarını da doğurmuştur. Yanaki Milton'un 1905 yılında gerçekleştirdiği Londra seyahati esnasında Charless Urban Trading Co'ya ait 300 numaralı kameranın Bioscope modelini satın alması ile birlikte, kardeşlerin ilk yaşayan görüntüleri kaydetmeleri ile yaşamı belgeleyen (kaydeden) kardeşler olarak anılmalarını sağlayan ve temelde Balkan coğrafyasında, özelde Makedonya topraklarında ve dahi çalışmanın örneklemi olan Makedon sinemasının doğuşuna öncülük eden isimler olarak literatürde yer edinmişlerdir. Meşhur kamera 300 ile ilk çektikleri film olan Baba Despina (Despina Nine) 114 yaşında, kasnağı ve dokunaklı görüntüsü ile yün eğirir iken ölümsüzleşecektir. "Despina Nine kayıtları, Makedonya'da mevcut olan antropolojik yapıya dikkat çekerek, etnik köken üzerine hazırlanan Domaći Posao (Yerli Üretim/Ev İşleri) ve Vodice (Dere) gibi filmlere ilham niteliğini oluşturmuştur.” (Dubrovacki, 2018), Sultan V. Mehmed Reşat'ın Selanik ve Manastır Ziyaret görüntüleri (1911), Sırp Kralı Aleksandar Karađorđević’in (1912) Manastır Ziyareti kayıtları ve Roman Heyeti'nin Resen, Gopes ve Manastır (Bitola) Ziyaretleri çekimleri, Balkan Savaşları ile I. Dünya Savaşı'ndan kesitler sunan görüntüler, Jön Türk Devrimi kayıtları, Manaki Kardeşlerin fotoğraf plaklarından edindikleri hareketli görüntülerden, film bantlarına akarak, tarihi kıymet niteliği taşıyan belgelerden, belgesellere doğru evrilmiştir.

İlgili gelişmeler 1952 yllında oluşturulan ilk uzun metrajlı film çekimlerine de zemin hazırlamıştır. “Manakiler 1921 yılında Manastır'da, iki sene sonrasında büyütecekleri alanların hayali ile ilk sinema salonunu açmışlardır. Kendi filmleri de dahil olmak üzere, beğendikleri yabancı ve farklı filmleri de gösterime sunmuşlardır. Ancak Manakiler, ilk aşkları olan, yaşamlarını idame ettirdikleri ve literatüre isimlerinin yer edinmesini sağlayan fotoğraf sanatını asla unutmamışlardır." (Dragana Garić, 2018), Manaki Kardeşlerin ardından 1918 yılında biri Lazo Tsapari tarafından Otel Amerika'da diğeri de Dimitri ve Kosta Chomu tarafından Selanik Oteli'nde olmak üzere iki yeni sinema salonu açılmıştır. Manastır'da sinema salonu anlayışı 1920'li yıllarda, otel yapılarından şehir tiyatroları binalarına taşınmıştır. Ancak Makedon sinema anlayışı Manaki kardeşlerin büyülü fotoğraf karelerinden doğarak, dramatik ve hüzünlü anlatımı ile film bantlarına kayıtlanarak, tarihsel süreç içerisinde, Balkan coğrafyasında yaşanan tarihsel, siyasi, ekonomik, hukuki ve sosyal gelişmelere koşut olarak yaşamış, tükenmiş ve defalarca yeniden dirilerek, hayatta kalma mücadelesini sürdürmüştür.

\section{Makedonya Üsküp’te (Skopje) bir film platosu: Vardar Film}

Makedonya'nın ilk prodüksiyon film kuruluşu olan Vardar film, 1947 yılında tesis edilmiştir. Kuruluşu itibariyle "yaklaşık 50 yıllık periyod içerisinde", (Vardar Film, 2007), çok sayıda unutulmaz nitelikte yapıtlara ve klasik sıralamasında filmlerin yapımına imza atan Vardar Film, sinema tarihinde Yugoslav ekolü olarak addedilen dönemin başat stüdyolarından biridir. Üsküp (Skopje) Makedonya'da tesis edilen Vardar film platosu, dönemin şartları içerisinde nicelik ve nitelik açısından kaliteli filmlerin çeşitlilik gösterdiği Yugoslavya Sosyalist Federal Cumhuriyeti'nde (YSFC) kurulan, yıldızı parlayarak 
unutulmazlar arasında yerlerini alan yapıtların üretildiği, yedi platodan biridir. Bosna Hersek Saraybosna'da kurulan (Sarajevo) Sutjeska, Surbistan Belgrad'da kurulan Avala, Hirvatistan Zagreb'de kurulan Jadran, Slovenya Ljubljana'da kurulan Triglay, Karadağ (Crna Gora-Montenegro) Budva'da kurulan Zeta ve Makedonya'da Üsküp’te (Skopje) kurulan Vardar film stüdyoları, Yugoslavya Sosyalist Federal Cumhuriyeti'nin sinema sanatında öncü rol üstlenmesine sebep, başat kaynaklar olarak sinema tarihi içerisinde yer edinmişlerdir. Balkan coğrafyası adına addedilen çok kültürlü, çok dinli, çok dinli, çok milletli ve çok etnili (etnik kökenli) tanım, Makedonya topraklarının yapısını da uhdesinde barındırmaktadır.

Bu düşünceden hareket ile, Yanaki ve Milton Manaki'nin Kamera 30o'ü ile çektikleri hareketli görüntüler ile doğan Makedon sineması, ilk günleri itibariyle, çok kültürlü, çok dinli, çok milletli ve çok etnili yapıların etkisi altında kalmıştır. Çok'luk kavramı ile ifade edilen farklılıklar, Makedon sinemasının daima aktif, başkalıkları barındıran, yaratıcı ve kültürel motiflerin işlendiği bir yapıya haiz olmasını sağlamıştır. Tarihi ve kültürel etkilerin gölgesinde gelişen Makedon sineması, doğuşundan günümüze değin Makedon tarihinin ve Balkan coğrafyasının kronolojik bir izdüşümü olma niteliğini de haizdir. Söz konusu izdüşüm, köklü tarihi tanıklı̆̆ının (belgelerin) belleklere sunulması (belgesele) misyonunu da üstlenmektedir. 1905 yllında Makedonya'da Manaki Kardeşlerin meşhur kamera 300 (Bioscope) makinesi ile fotoğraf plaklarından edindikleri hareketli görüntülerinden film bantlarına aktarımları ile elde ettikleri belgesel niteliğini haiz çalışmalar, salt Makedon topraklarında değil, tüm Balkan coğrafyasında bir ilkin gerçekleşmesi olarak sinema tarihinde kayıtlanmaktadır. Manaki Kardeşler'in elde ettikleri canlı kareler, Balkan Savaşları, I. ve II. Dünya Savaşları ve türevleri mezalimlerin yaşanması sürecinde sekteye uğramış olsa da sinema sanatı Balkan topraklarında, halkın desteğini ve tarihsel süreç içerisinde hükümetlerin teşviklerini hiçbir dönem yitirmemiştir.

Sinema sanatına büyük bir hayranlık duyan Yugoslavya Sosyalist Federal Cumhuriyeti’nin (YSFC) kuruluşunda başat aktör olan ve Güney Slavları Yugoslavya üst kimliğinde birleştiren Devlet Başkanı Josef Broz Tito, sinema sanatının gelişmesi adına da ihtiyacı hissedilen devlet desteğini sunmuştur. Sanatın hemen her alanını destekleyen Tito, dünya tarihi uhdesinde emsali görülmemiş bir karara imza atarak, devlet arazilerinin sinema sanatının gelişmesi adına tahsis edilmesini sağlayarak, II. Dünya Savaşı başta olmak üzere tarihsel süreç içerisinde yaşanılan mezalimleri ve işgalleri de göz önünde bulundurmak gerekliliği içerisinde, dönemin mevcut şartlarına binaen ciddi sayılabilecek miktarda devlet bütçesini ayırarak, sinema sanatına gönül veren ve sinema disiplini dahilinde kendini yetiştirmek isteyen dimağları da yurtdışına eğitim görmeleri adına gönderilmelerini teşvik etmiştir. Ayrıca ülkesi Yugoslavya'da Güzel Sanatlar alanında özgün, nitelikli, kaliteli ve yaratıcı yapıtların ortaya çıması adına da Üniversiteler ve kurslar açılmasını sağlayarak, nitelikli işgücünün yetişmesini de sağlamıştır.

Yugoslavya halkı ve devletinin destekleri ile savaşların, işgallerin ve yağmaların hezimetlerinin atlatılması adına ülkenin her bir Federatif Cumhuriyet konumundaki topraklarına açılan birer film platosu, Makedonya'da ve dahi Balkan topraklarında sinema sanatının gelişimi adına başat katkıyı sağlamıştır. Film stüdyolarının tesisi ile kısa süre içerisinde başarılı, verimli, yaratıcı ve süreklilik arz eden gelişimin sağlanması, dünya sinema tarihi içerisinde Yugoslav Ekolü tabirinin de yerleşmesine sebebiyet vermiştir. Yıldızı parlayan yapıtların üretimi, sinema alanında bilgi ile sürekli donanan sinema emekçilerinin varlı̆̆ı, Yugoslavya hükümetinin destekleri ile edinilen ekipmanların varlığı, diğer sanat dallarına koşut olarak gelişen Yugoslav sinemasının nicelik ve nitelik adına taçlanması sonucunu doğurmuştur. Partizan Hareketi'nin desteklediği Tito'nun hükümette kaldığı 1945-1980 yılları, Vardar Film Platosu aracılığı ile Makedon sineması başta olmak üzere, Avala, Sutjeska, Jadran, Triglay ve Zeta film platolarının dünya çapında elde ettikleri başarıları ile anılmaktadır. Çeşitliliğin ve kaliteli yapıtların 
sergilendiği 1945-1980 yıllarında ön plana çıkan yapıtlar, Balkan sinemasının dünya literatüründe yer edinmesini sağlamıştır.

Dönemin mevcut şartları ile değerlendirildiğinde, zamanın en ihtişamlı, en çok izlenen, en başarılı ve en verimli çalışmaları Lazar Stojanovic, Sasa Pertrovic, Dusan Makevejev, Aleksandar Petrovic, Zelimir Zilnik ve Zivojin Pavlovic isimlerinin başı çektiği Belgrad (Sırbistan) grubu olarak adlandırılan Avala film stüdyosu ekibi ile Ante Babaja, Krsto Papic ve Vatroslav Mimica'nın öne çıktığı Zagreb (Hırvatistan) grubu olarak addedilen Jadran film platosu öncülerinin azımsanamayacak nitelikte ve nicelikte ürettikleri yapıtlardan oluşmaktadır. Yugoslav ekolü olarak addedilen film platolarının ürettikleri yapıtlar arasında şüphesiz ki Vardar Film platosunun eserleri de yadsınamayacak nitelik ve nicelikte zenginliğe ve çeşitliliğe sahiptir. Ayrıca "Üsküp’te yer alan Vardar Film Platosu, 1952 yılında Makedon sinemasının ilk uzun metrajlı çalışması olan Frosina filmini çekmişlerdir.” (Goulding, 2002:233). Drama türünde çekilen 88 dakikalık senaryosunu Vlado Malevski'nin yazdığı Frosina filminin yönetmenliğini Kiro Bilbilovski üstlenmiştir. Dönemin şartları dahilinde, Vardar Film’in başarısı, hükümetin de ilgisini çekerek, Vardar Film’i destelemek adına Makedonija (Makedonya) Film dağıtım şirketini kurmuştur. İlk uzun metrajlı filmin etkileri henüz dinmeden, 3 yllın ardından (23.06.1955) Makedon Şair Slavko Yanevski'nin (Günümüzde Makedonya Struga şehrinde büstü mevcuttur.) senaryosunu yazarak, Altın Arena ödülünü kazandığı Kurt Gecesi (Vucja Noc/Volçya Nok) filmi çekimi tamamlanmış ve gösterişli bir prömiyer ile halka sunulmuştur. Rejisörlüğünü France Stiglic’in üstlendiği 83 dakikalık Kurt Gecesi (Vucna Noc) filminin, yönetmenlik görevini ise Branko Mihajlovski ile Ljube Petkovski üstlenmişlerdir.

Uzun metrajlı film heves ve isteği, Vardar Film emekçilerini yeni başarılar elde etme yönünde motive ederek, üçüncü uzun metrajlı film olan Küçük İnsan (Mali Čovek) Miomir Denic yönetmenliğinde, diğer filmlerde olduğu gibi standart siyah beyaz teknik ile 91 dakikalık yeni bir eserin Makedonya sinemasına kazandırılmasını sağlamıştır. Senaryosunu Zivojin Cukulic, Josip Novak, Djordje Radisi ve Svetolik Maricic’in yazdıkları Küçük İnsan (Mali Čovek) filminin prömiyeri 1957 yılına tekabül etmektedir. Aynı yll (1957) içerisinde uzun metrajlı filmler ile birlikte, Dimitar Kostarov'un yönetmenliğini üstlendiği komedi tarzındaki 25 dakikalık Neşeli Badanacınnn Hediyesi (Podarok Od Veseliot Moler) filmi, Makedon şair Slavko Yanesvski'nin senaryosunu yazarak, aynı zamanda yönetmenliğini de üstlendiği drama tarzındaki 18 dakikalık Demir Parmaklarm Ardındaki Güneş (Sonce Zad Reshetki) filmi ve Dimitrie Osmanli’nin yönettiği drama tarzındaki 18 dakikalık Kuklaların İsyanı (Bunt Na Kuklite) kısa filmleri de Makedon sinema literatürü içerisinde yer edinen öncü çalışmalar olarak kayıtlanmışlardır.

23 Haziran 1958 yllında, senaryosunu Djordje Abadzijev, Marion Michelle ve Trajce Popov'un yazdıkları, Zivorad Zika Mitrovic’in yönetmenliğini yürüttüğü ve Makedon sinematografisi içerisinde ilk renkli film olma özelliğini taşıyan, 1 saat 36 dakika süren, macera, tarih ve drama olarak kategorize edilen Mis Stone (Bayan Stone) filmi Makedon sinemasına kazandırılmıştır. 20. Yüzyıl Balkan tarihinde, Osmanlı İmparatorluğuna karşı hareket yürüten Amerika başta olmak üzere siyasi güçlerin misyoneri olarak faaliyetler yürüten Ellen Maria Stone'un hikayesinin betimlendiği Mis Stone filmi Edinburg (1960) ve Wu Delhi (1961) film festivallerinde önemli ödüller kazanmıştır. 9 Kasım 1959 yılında, senaryosunu Arsen Diklic, Branko Bauer ve Slobodan Glumac'ın yazdıkları, yönetmenliğini Branko Bauer’in yürüttüğü 97 dakikalık drama tarzında Üç Anne (Tri Ane) isimli ve yine aynı yıl, senaryosunu Slavko Janevski’nin yazdığı roman uyarlaması tarzında 89 dakikalık Viza Na Zloto (Kötülüğün Vizesi) isimli iki önemli uzun metrajlı yapıt Makedon sinemasına kazandırılmıştır. Alexander Pushkin'in romanından Akos Tolnay ile Gino De Santis'in katklları ile uyarlanan, yönetmenliğini William Dieterle'nin üstlendiği, 117 dakikalık drama tarzında Il Vendicatore 
(Dubrowsky) filmini 11 Şubat 1959 tarihinde İtalyan Heperia Film ve Makedon Vardar Film ortak yapımı film çekilerek, uluslararası nitelikte ilk ortam yapım filmi niteliğini haiz olarak Makedon Sineması tarihinde kayıtlanmıştır.

1961 yllı itibariyle, Vardar Film pek çok yeni, farklı ve özgün yapıta daha yoğun ilgi ve teknik imkanlar donatılmış filmlere imza atmıştır. Bilhassa, Dimitrie Osmanli’nın yönettiği, Frida Filipovic'in senaryosunu yazdığı komedi tarzında, 99 dakika süren Mirno Leto (Sessiz Yaz/A Quiet Summer) isimli filmi, Makedonya topraklarında mevcut olan Etnik müze olarak addedilen coğrafyanın hikaye dahilinde tasvirinin gözler önüne sunulması sebebi ile Makedon sinemasının önem arz eden yapıtları arasında yerini almıştır. Makedonya özgürlük savaşları olarak anılan ünlü tarihi bir grubun, 20. yüzyılın başlarında Osmanlı İmparatorluğu'na karşı verdikleri mücadelenin konu edildiği, yönetmenliğinin Zivorad Zika Mitrovic tarafından üstlenildiği, Jovan Boskovski tarafından kaleme alınan, 106 dakikalık tarihi ve drama tarzında çekilen Solunski Atentatori (Selanik Suikastçllarl/The Salonika Terrorists) (Solunski Atentatori, 1961), filmi özellikle, Osmanlı İmparatorluğu'na dair fikirlerin sinema sanatına yansıması olarak yorumlanması sebebi ile Makedon Sinema tarihi içerisinde önemli yapıtlar arasında literatür içerisindeki yerini almaktadır. 14 Haziran 1964 tarihinde savaş ve dram kategorisinde 87 dakika süren, senaryosunu Tome Arsovski ile Jovan Boskovski’nin üstlendikleri, Ljubisa Georgijevski ile Miomir Stamenkovic’in yönetmenliğini yürüttükleri Pod İsto Nebo (Aynı Göğün Altında) adlı film, özellikle savaş ve aksiyon konulu filmlerin yolunu açmış ve amatör sinema emekçilerini de yüreklendirmiştir. Aynı yıl ulusal düzeyde, amatör filmlerin gösterimde olacă̆ bir film festivali de düzenlenmiştir. Makedon sinemasının artan ivme gösteren yükselişi, Üsküp Televizyonu'nun (TV Skopje) kuruluşuna da etki sağlamıştır.

1965 yılı itibariyle, Makedon sineması gün geçtikçe artan nicelik ve nitelikte sinema yapıtları ile dünya sinematografi literatüründe yerini almıştır. Özellikle; "1965 yılı yapımı Dani İskusenja (Etüt Günleri), 1966 yılı yapımı Do Pobede İ Dalje (Zafere Doğru ve Ötesi), 1967 yllı yapımı Kuda Posle Kise (Yağmur Sonrası Nereye), 1967 yll yapımı Makedonska Krvava Svadba (Kanl Makedon Düğünü) ile Memento, 1968 yılı yapımı Planina Gneva (Öfke Dağı), 1969 yılı yapımı Republika u Plamenu (Alevler İçindeki Cumhuriyet), 1970 yll yapımı Cena Grada (Kentin Bedeli), 1984 yll yapımı Gefährliche Spur (Opasni Trag-Tehlikenin Peşinde), 1986 yll yapımı Die Rache (Revenge-İntikam) ve Glueckliches Neuses'49 (Mutlu Yillar'49), 1994 yılı yapımı Pred Dozdot (Pre Kise-Yağmurdan Önce), 1997 yılı yapımı Angeli Na Otpad (Kuşatmadaki Melekler) ve Preku Ezero (Preko Jezera/Nehrin Ötesi)” (Filmska Banka, 1998), filmleri ile Oscar ödülleri de dahil olmak üzere, sayısız ödül alarak, sayısız festivallerde başarı kazanarak, dünya sinema tarihi içerisinde Makedon sineması olarak yer edinmeyi başaran eserler üretmişlerdir. Özellikle, 1984 yll yapımı Gefährliche Spur (Opasni Trag-Tehlikenin Peşinde) filminin çekimi adına, Centar (Belgrad) Film, Avala Film, Zeta Film ve Viba Film (Ljubljana) platolarının iş birliği ile üretilmesi sebebi ile prodüksiyon yönündeki ortak çalışmaların önemi ortaya çıkmıştır. Prodüksiyon iş birlikleri adına hissedilen ihtiyaca binaen ortak film yapımlarını destekleyen prodüksiyon şirketlerinin de kurulması da gündeme gelmiştir.

Josef Broz Tito’nun 1980 yllındaki ölümünün ardından başlayan ve 2000 yıllarına değin süren, geçmişteki etnik zenginlik düşüncesinin etnik temizlik saplantısına dönüşen kaosun yaşanması sebebi ile 1991 yılında Makedonya'nın, Slovenya ve Hırvatistan'ın hemen ardından bağımsızlıklarını ilan etmeleri ile birlikte, Balkanizasyon sürecine itilen diğer Yugoslavya Sosyalist Federal Cumhuriyetleri'nde (Slovenya, Hırvatistan, Bosna-Hersek, Strbistan, Karadağ, Kosova) olduğu gibi Makedonya'da da sinema sanatı da dahil olmak üzere, tüm sanat, bilim, spor, sağlık ve kültür alanları onarılması güç zayiata uğramıştır. Bağımsızlığını ilan ettiği 1991 yılından günümüze değin, yeniden 
dirilmeye çalışan Makedonya sineması, Vardar film platosunun açtığı çı̆̆ırın izinden gitmek ile birlikte, geçmiş yıllardaki başarılı yapıtların ivmesini günümüzde yakalayamamıştır. Geçmişin ününü kullanan ve sinematografik mirasının faydalarını günümüzde de hisseden Makedon sineması, ekonomik sıkıntılar sebebi ile de zorlu günler yaşamaktadır. Ancak, "insanlık için, aydınlık için, gelecek için sinema yapıyoruz, filmlerimiz insanlık mücadelesi içindir" özdeyişini düstur edinen Makedon sinema emekçileri, geçmiş ylllarda ve hemen her alanda olduğu gibi küllerinden doğan ülkenin izinden giderek, Makedon sinematografisini nicel ve nitel anlamda çeşitlendirerek, zenginleştirecek eserler üretmeye devam edeceklerdir.

\section{Kültürlerarası iletişim bağlamında Makedon sinemasını okumak}

Yedinci sanat dalı olan sinemanın Makedonya toprakları dahilinde gelişmesi hususu şüphesizdir ki günümüzde Eski Yugoslavya olarak isimlendirilen, literatürdeki okuma ile Yugoslavya Sosyalist Federal Cumhuriyeti (YSFC) dönemine değin uzanır. Avrupa ülkeleri ve Rusya ile tampon bölge konumunda olan, dönemin bağımsızlar bloğunun bir ittifakı rolünü üstlenen ve Mareşal Tito’nun kristal ülkesi, "Kardeşlik ve Birlik" düsturu ile (Bratstvo i Jedinstvo - Brotherhood and Unity) kenetlediği Güney Slavları'nın rüya ülkesi Yugoslavya Sosyalist Federal Cumhuriyeti’nin (YSFC) uhdesinde barındırdığı etnik unsurların kültürlerarası iletişim argümanlarının sekteye uğratılma çabaları ve farklılıkların keskin çizgiler ile ayrımsama çalışmalarının neticesinde, huzursuzluk, kargaşa ve dahi etnik çatışmaların yaratılması planları çerçevesinde, yedi sınır, altı Cumhuriyet (Bosna-Hersek, Hırvatistan, Karadağ, Makedonya, Sırbistan, Slovenya), beş ulus, dört dil, üç din, iki özerk bölge (Kosova ve Voyvodina) veya iki alfabe (Latin ve Kiril) ve nihayetinde çağımızın en trajik savaşlarından birinin neticesinde, bölünme, parçalanma ve dağılma anlamlarına denk gelen Balkanizasyon sürecini etüt eden, özlemle gözyaşı ülkesi olarak anılan Güney Slavları'nın ülkesi Yugoslavya, sinemadan spora, kültürden teknolojiye hemen her alanda dünya tarihinde başarı olarak addedilen gelişmelere ismini vermiştir.

Makedonya etnik çeşitliliği, kültür zenginliği, dil çokluğu, milliyetçilik akımları, dini inanç hasletleri ve türevleri ile kozmopolit bir yapının simgesi niteliğini taşımaktadır. Balkan toprakları uhdesinde barındırdığı farklılıkları yüzyıllar süresince aynı potada eritmeyi başarabilmiş ve farklılıklarını zenginliklere çevirebilme yeteneğine sahip olmuştur. Ancak, farklllıklar ile bir arada yaşam kültürünün etüt edildiği en önemli coğrafya olan Balkan topraklarında mevcut olan etnik çeşitlilik, tarihin belirli dönemlerinde büyük mezalimlerin yaşanmasına da sahne olmuştur. Çok etnili (etnik kökenli), çok kültürlü, çok dinli, çok dilli ve çok milletli olarak addedilen Balkan coğrafyası, sahip olduğu tüm söz konusu farklılıklarını sanattan edebiyata, mimariden müziğe her bir kültür yapısına yansıtma yetisini sergileyebilmiş bir bölgedir. İsminden sınırlarına, yönetim şeklinden hükümranlı̆̆ına değin başat öğelerinin tarihsel süreç içerisinde defalarca değişime uğradı̆̆ Balkan coğrafyası, tecrübe ettiği değişimleri, uhdesinde barındırdığı farklılıkları ve yüzyllar süresince biriktirdiği kültürel öğelerini sanat dallarından yaşam pratiklerine değin her bir alana yansıtmayı başarabilmiş bir coğrafyadır. Balkan topraklarının kalbinde yer alan günümüzün Makedon Cumhuriyeti, edindiği tarihi ve kültürel mirasını diğer sanat dallarında olduğu gibi sinema sanatına da eklemlemeyi başarı ile gerçekleştirebilmiştir.

Yugoslavya Sosyalist Federal Cumhuriyeti'nin (YSFC) benimsemiş olduğu Özyönetim sistemi, sinema sanatı da dahil olmak üzere her bir bilim ve sanat dalı ile kültürel alanda devlet denetiminin ortadan kalkması anlamına gelmektedir. Özyönetim sistemi ile halkın kendi kendini yönetme hakkı tanınarak, halkın devlet yönetimine katılımları desteklenmiştir. Özyönetim sistemi temelde, özgür düşünceden hareket ile özgün yapıtların üretiminde, diğer sanat dallarında olduğu gibi sinema sanatında da sansür 
ve denetleme kaygıları güdülmeden yenilikçi düşüncenin ön planda tutulduğu bir anlayışı salık vermektedir. Özyönetim elbette ki sınırsız özgürlük kavramına eş değer bir nitelik taşımamaktadır. Ancak, Yugoslavya Özyönetim sistemi, devletin güdümünde yer alan sansür ve denetim kozlarını kullanmaktan imtina etmiştir. Zira, yönetim zafiyetinin en aza indirgenmesini amaç edinen özyönetim sistemi ile taraflara belirli ölçütlerde özgürlük tanınmaktadır. Ayrıca, devlet yönetimi anlayışının baskı ve sansür unsurlarından da kaçındığını ifade etmek mümkündür. Bu sebeple, sansür ve denetim tutumlarının devlet eli ile gerçekleştirilmesi, Yugoslav Özyönetim sistemi tarafından benimsenen bir durum olmamıştır. Sinema sanatına vakıf, ilgili konuda eğitimli ve tecrübeli bireylerden oluşan yapım şirketleri, Üniversiteler, sinema emekçileri ve dernekleri (birlikler) ile türevleri bireylerin oluşturduğu kurumlar aracılığı ile ihtiyacı hissedilen denetimin gerçekleştirilmesinin gerekliliğinin savunulduğu idealist bir düşünce etiği olan Özyönetim sistemi, Yugoslavya topraklarında bilimin, sanatın ve kültürel gelişmelerin başarısı konusunda başat rol oynamıştır.

Özyönetim sistemi ile birlikte Makedon sinema sanatı, kısa süre içerisinde nitel ve nicel anlamda başarılı yapıtların elde edilmesini sağlamıştır. Makedon sinema anlayışı, dünya sinema tarihi içerisinde, 1905 yılında Manaki Kardeşler'in çabaları ile başlayarak, Yugoslavya'nın dağılma sürecinin başlangıcı olan 1991 yılına değin, özgün, nitelikli, kaliteli ve yaratıcı yapıtlar üreterek, dünyanın sayılı sinema sanatı üreticileri arasında yer edinerek, sayısız düzeyde film ihraç etme başarısı yakalamışlardır. Kamu kurumu niteliğini haiz Vardar film stüdyosundan, "Makedonija Film ve Gradski Kina-Skopje" (Cinematheque Of Macedonia, Production, 2012), platolarına değin üç önemli Enstitü olarak addedilen kurumun varlığı ile Makedon sineması, ülke ekonomisi adına da ciddi oranlarda katkı sağlama gücüne erişmiştir. Kısa süre içerisinde sektör haline gelen Makedon sinema sanatı, Film Yapımcıları Derneği’nin etik ve özverili çalışmaları ile ulusal ve uluslararası nitelikte iş birlikleri içeren çalışmaların gerçekleştirildiği bir yapıya kavuşmuştur. Belge ağırlıklı ve belgesel nitelikli yapıya sahip Manaki Kardeşler’in 1905 yılından başlayarak kayıt ettikleri yün eğiren kadınlar, panayır alanları, düğün ve eğlence kareleri, devlet erkanının resmi ziyaretlerine dair protokol çekimleri, gezdikleri şehirlerden kesitler ve türevleri başta olmak üzere örneklerini çoğaltmamızın mümkün olduğu gündelik yaşam pratiklerine dair ve dahi Makedon çok kültürlü yapısının ortaya çımasını sağlayan hareketli görüntülerden, 1952'li yıllara uzanan süreçte ulusal ve uluslararası niteliğe haiz ortak yapımların varlığına değin, kısa ve uzun metrajlı pek çok yapıt, homojen ve yaratıı Makedon sinemasının süratli gelişimini gözler önüne sermektedir.

Makedon sinema filmlerinin başarısı, yeni yapımların sürdürülebilirliğini sağlamış, başta Manastır (Bitola) şehri olmak üzere pek çok yeni sinema salonunun açılmasını da teşvik etmiştir. Pek çok şehirde düzenlenen film festivalleri, dünya sinema emekçilerini Makedonya başta olmak üzere, Balkan topraklarına çekmeyi başarabilmiştir. Düzenlenen nitelikli festival organizasyonlarının ülke ekonomisine ve ülkenin diğer parametrelerine (turizm, ticaret, sanat ve türevlerine) katkıları şüphesiz ki yadsınamaz bir kıymettir. Makedon coğrafyasında sinema sanatı başta olmak üzere yaşanan hızlı kalkınma süreci, ekonomi düzleminde de desteklerin artması ile gösterim alanlarının sayılarının çoğalması, teknik alt yapı ihtiyaçlarının temini, sinema platolarında istihdam edilen işgücünün nicelik ve nitelik anlamında artmasına da etken teşkil etmiştir. İşgücünün nicelik ve nitelik bağlamında yüksek ivme kazanması, eğitimli sanatçların, oyuncuların, teknik personelin, uzmanların da kendilerini geliştirme yönünde motivasyonlarının yükselmesi ile sonuçlanmıştır. Yüksek motivasyon ile çalışan sinema istihdamı deneyim ve birikimlerini sinema sanatı ile birlikte farklı sanat ve bilim dallarına da aktarmayı başarabilmişlerdir. Yugoslavya Sosyalist Federal Cumhuriyeti'nde (YSFC) devlet destekleri ile emekleyen Makedon sineması, kısa bir zaman dilimi içerisinde, domino taşı etkisi ile belgesel nitelikli yapımlardan dram mahiyetindeki eserlere, komedi tarzından tarihi yapıtlara ve dahi animasyon temelli 
eğlence unsurlarını barındıran pek çok filmi ortaya çıkarmışlardır. Üretilen eserler dahilinde şüphesiz ki edebiyat yapıtlarının klasikler haline dönüştüğü yapıtların, sinemaya uyarlamaları da halkın yüksek düzeyde beğenisini kazanmıştır. Ayrıca, hükümetlerin kitle iletişim araçlarını propaganda unsuru olarak addetmeleri gerçeği, sinema sanatına da sirayet ettiğinden, devlet destekli üretilen tehlike unsuru barındırmayan ve propaganda nitelikli filmlerin Makedon sinemasında da yer edindiklerini ifade etmek mümkündür.

Makedon sinemasında, salt hikaye anlatıcılığı sınırlarını bertaraf ederek, bünyesinde barındırdı̆̆ 1 kültürel mizanseni izleyicileri rahatsız etmeden temsillerin, anlatının, mekanın ve karakterlerin doğallığı içerisinde, özgün bir strüktür şeklinde izleyicisine sunar. Camiler, manastırlar, kiliseler, sinagoglar mizanseni içerisinde, mutlu, huzurlu ve uyumlu yaşamların coğrafyası algısı yaratılır. Anlamlı, doğal ve sade bir yapıya bürünen dış mekan, muhalif söylemleri, dram hissiyatını, belirli durumlarda -ihtiyacı hissedilen düzeyde propaganda- unsurlarını, farklı katmanlara ayırarak, toplumsal gerçekliği veya kurgular ile işaret edilmek istenen detayları olağanca gücü ile izleyicilerine hissettiren Makedon sineması, yaşamın getirdiği çözümsüzlük duygusunun aşılma aracı olarak betimlenir. İdeolojik kurgular ile de sinema tarihi dahilinde sinıflandırılan Makedon sineması, farklılıklar ile birlikte yaşam kültürünün duygu ve düşüncelere en doğal şekli ile dönüşümü olarak tarif edilmektedir. Ayrıca Makedon sineması pek çok senarist ve sinema sanatçısına göre, bir hayal ürünü olarak tariflenir, sinema düşlerin gerçekçi kılınması adına bir araç görevi taşımaktadır. Zira, sinemanın düşünce, görüş, propaganda unsurları başta olmak üzere, düş ve yaşam pratiklerinin benimsetilmesi konusunda en başarılı araçlardan biri olduğunu ifade etmek yanlış olmayacaktır. Yugoslav sineması veya daha geniş bir bakış açısı ile değerlendirildiğinde Balkan sinemasının hemen her bir yapısı, Makedon sinemasına da sirayet etmiştir. Bu düşünceden hareket ile literatürde, devrimci, militan, propaganda, siyasi ve karşı devrimci sinema olarak addedilen yapıt türlerine, Makedon sinemasında da rast gelmek mümkündür.

Özgür düşünce düzleminde yolu açılan Makedon sineması emekçileri, yeni kurulan film platoları ve şirketlerinin de sayısının artması ile birlikte, banka ve ticari kuruluşlardan düşük oranlarda faiz sisteminin benimsendiği geri ödeme koşullarına sahip kredi kullanım hakkına erişim sağlayarak, Makedon sinemasının altın çağını yaşamışlardır. Makedon sinemasında Avangart film dönemi olarak addedilen yeni bir dönemin başlaması ve tarzlarını yenileyen uluslararası nitelikleri gözeten sinema emekçilerinin varlığı, sinema yapıtlarının çeşitlenmesi ile sonuçlanmıştır. Ancak, 1970 yılları itibariyle, Makedon sineması da dahil olmak üzere, Yugoslavya sınırları dahilinde varlık gösteren diğer film platolarının yapıtları mevcut hükümeti rahatsız etmeye başlamıştır. Çünkü sinema sanatının gelişimine dair ayrılan, dönemin şartlarına göre değerlendirildiğinde yüksek miktarlara tekabül eden yüksek bütçeler, tanınan vergi muafiyetleri gibi ayrıcalıklar, sinema eğitimi almak isteyen sinema emekçilerinin özellikle yurtdışı ülkelerinde eğitim almalarını destekleyen programlar ile gelişen sinema anlayışı, hükümetin istediği fikirlerin kitlelere yayılması amacını taşımakta idi. Zamanla yönetimin istekleri dışında hazırlanan yapıtların varlığı, mevcut hükümetin Özyönetim olarak tanımladığı anlayışın eleştirilmesini gündeme getirmiştir.

Kitleleri yönlendirme kabiliyetini haiz sinema aracılığı ile gelişen eleştirilerin farklılığı ile çokluğu mevcut hükümeti rahatsız etmiştir. Sinemayı bir propaganda aracı olarak da kullanan hükümet, zamanla halkını planladığı şekilde yönlendiremediği gerçeği ile karşı karşıya gelmiştir. Hükümetin halkını dilediği şekilde yönlendirememe kaygısı, sinema sanatı üzerinde geçmişte var olmayan biçim ve süreçlerde sansür ve yasaklama uygulamalarının yürürlüğe getirilmesine neden olmuştur. Alışı olmadıkları sansürlere, yasaklara ve kısıtlamalara maruz kalan Makedon sineması emekçileri, Siyah Dalga (Black Wave) olarak addedilen hükümeti eleştiren ve yasaklara karşı durma edimi gösteren 
yapıtlara ağırlık vermişlerdir. Dönemin mevcut şartlarından ve sosyal, siyasi, ekonomik, kültürel ve teknolojik değişimlerinden bağımsız hareket edilmesinin mümkün olmadığı sinema sanatı, Makedon sinemasında da aksi yönde işlememiştir. Makedon sineması da İtalya'da gelişen ve yoğunlaşan, ötekiliği ve ayrıştırmacı düşünceyi irdeleyen, yalnızlık hissiyatını önemseyen, İtalyan Yeni Gerçekçi Akımı'ndan da etkilenerek, hükümete karşı muhalif tavırların merkeze alındığı yapıtlar sergilemeye başlamışlardır. Özellikle, Polonya, Çekoslovakya, Küba ve Macaristan da gelişen Marksist düşünceyi düstur edinen sinemanın izdüşümü, Makedon sinemasına da sirayet etmiştir.

Dogmatik yapılardan arınmayı, bürokratik engellerden sıyrılmayı, her çeşit yasak, sansür ve denetimden uzaklaşmayı, siyasi, ekonomik, ironi ve türevleri her türlü dayatmadan soyutlanarak, özgün ve yaratıcı eserler üretmek adına çaba gösteren Makedon sinemasının temel dayanağı, çağdaşlaşma düsturu olmuştur. Dramatik temaların ağırlıklı olarak işlendiği Makedon sineması, mekan, senaryo ve karakter üçlemesine başat önem vermişlerdir. Psikolojik tahlillerin de ağırlıklı olarak işlendiği Makedon sinema yapıtlarında, senaryonun özgünlüğü filmin özgürlüğü ile eşdeğer tutulmuştur. Özgür ve özgün yapıtların evrenselleşmeyi ve çağdaşlaşmayı beraberinde getireceğine inanan Makedon sinema emekçileri, senaryo yazımı konusunda, senaryo okulları açarak kurumsallaşan ve senaryo yazım tekniklerinin gelişimine ayrı bir önem addederek gelenekselleşen bir yapıyı haizdir. Estetik kaygıların daima ön planda yer aldığı Makedon sineması, ışıktan sese, mekandan karaktere yapıtlarında yer verdikleri her bir eğretilemeye (metafora) ayrı birer anlam yüklediklerinden, kurdukları düşlerin gerçeğe dönüşümünün eğretilemeler (metaforlar) aracılığı ile sağlanabileceğine inanmaktadırlar. Soyut hayallerin, görüntüler aracılığı ile gerçeğe dönüşmesinde başat rol üstlenen sinema sanatı, Makedon sinemasında semboller (imgeler) ile anlam bulmaktadır. Makedon sinema emekçilerine göre semboller özdeşleşme duygusunu da beraberinde getirmektedir. Bir mekan, karakter, olay ve türevi ile özdeşleşebilen izleyici, filmin bütününü de içselleştirebilmekte ve filmi sunulmak istenen tüm boyutları ile anlamlandirabilmektedir.

\section{Sonuç}

İsminden yönetim şekline, sınırlarından hükümranlığına, demografik yapısından istikrar politikalarına değin temel unsurlarının tarihsel süreç içerisinde, sayısız defa değişime uğradığı Balkan coğrafyası, Balkan milletlerinin beklentilerini, korkularını, düşlerini, sorunlarını ve umutlarını uhdesinde barındıran ve yaşanılan süreçlerin izlerini günümüzde de taşıyan bir yapıya sahiptir. Tarihsel ve kültürel birikimini edebiyattan sinemaya, mimariden müziğe her bir sanat dalına yansıtan Balkan coğrafyası, çok kimlikli ve çok kültürlü yapısından kaynaklanan çok renkliliği ve çok çeşitliliği ile pek çok sanat dalında farklı, özgün ve nitelikli yapıtları ile ön plana çıkmayı başarabilmiş bir alandır. Makedon sineması da Balkan coğrafyasının kültürel birikiminin yansıtıldığı, çok kısa zaman dilimleri içerisinde varlığını kanıtlayabilme başarısı göstermiş, yapıtları ile isminden söz ettirerek, dünya sinema tarihi içerisinde yer edinebilmiş, çok renkliliğini ve çok sesliğini doğal ve naif motifler ile yapıtlarında işleyebilmiş, düstur edindiği nosyonları izleyicilerine en sade şekli ile aktarabilme gücüne erişebilmiş, sürekli yara alarak tekrar silkinme dirayetini gösterebilmiş bir özgün ve yaratıcı düşünce yapısıdır. Temanın, olay örgüsünün, kronotopun (uzam/zaman algısı), kimlik temsillerinin ve mekan bağlamlarının bir harmoni içerisinde sergilendiği Makedon sineması, anlatım öğelerini farklı film türleri içerisinde harmanlayabilen, Balkan coğrafyasına ayna tutarak, coğrafi öğelerin temsili niteliğini kazanmış bir sanat dalıdır. Ekonomik temelli konumlandırılan sinema sanatı görüşlerinin aksine, kıt sayılabilecek kaynaklar ile yaratıcı ve özgün yapitların icrasını başaran Makedon sineması, amatör, bağımsız, ulusal, etnik ve küresel (uluslararası) olmak üzere, her bir kategoriye dahil olma yeteneğini kanıtlamıştır. 
Kategorize edilmesi ve kavramsal çerçevesinin çizilmesi güç olan Makedon sineması, tarihinin hiçbir döneminde diğer sanat ve bilim dalları tarafından desteksiz bırakılmamıştır. Edebiyat alanında emek veren sanatçllardan tiyatro sanatçllarına değin hemen her disiplin, Makedon sinemasının gelişimi ve özgün eserlerinin üretimi adına birlikte hareket etme kabiliyetini göstermişlerdir. Daima sınır ötesi coğrafyalara erişmeyi hedefleyen ve bölgesel kalma endişesi yaşayan Makedon sineması, kıtaları aşan ve coğrafyaları dolaşan yapıtlar üretme heves ve azmini daima koruma başarısını gösteren sinema emekçilerinin meşakkatli çalışmaları ile büyük başarılar elde etmişlerdir. Kuşak çatışmalarından, aile bağlarına, savaş temalarından güncel gelişmelere değin geniş perspektifte kurguladıkları sinema yapıtlarını, dramdan komediye, belgeselden maceraya, etnikten savaş filmi kategorilerine değin farklı alanlarda eserler üretmişlerdir. Satır aralarına gizlenen kültürel ve tarihi mizansen, Makedon sinemasında daima varlık göstermiştir. Hükümet destekli başarılı (altın çă̆) yapıtların üretim sürecinden sansür, yasaklama ve kısıtlama evrelerine, siyasi eleştirilerin hedeflendiği eleştirel bakış açllarından Yugoslavya Sosyalist Federal Cumhuriyeti'nin (YSFC) dağılma süreci sebebiyle yaşanan durağanlık dönemine değin, defalarca yükselen, durağanlaşan, silkinen, çabalayan ve yeniden dirilmek için çırpınan Makedon sineması, yapıtlarında umutsuzluğa yer vermeden, izleyiciyi yormadan, kolayı tercih etmeden, tekrara düşmeden, en dramatik vakalarda dahi mizah unsurunu (kara mizah) kaybetmeden yapıtlarını nicel ve nitel bağlamda zenginleştirme azmini sergilemiştir.

Makedon sineması, kültürünün uhdesinde barındırdığı müzik unsurunu her bir yapıtında en belirgin ve en naif şekli ile desenlemiştir. Ağırlıklı olarak Balkan ezgilerinin yer edindiği film müzikleri, Makedon sinema yapitları dahilinde bütünlük oluşturmuştur. En dramatik, en hazin ve en kederli sahnelerde duyulan Balkan müziğinin coşkusu, izleyicilerini yormadan, filmin izdüşümüne renk katmaktadır. Zira Balkan müzikleri, farklı etnik kökenleri aynı inançta ve aynı düşüncede birleştiren başat argümanlardan biri olarak addedilmektedir. Ana temasının gerçek yaşamlardan temin edildiği, belirli kesitlerin senaryo gereği kurgulanarak, gerçeğe en yakın şekli ile izleyiciye sunulduğu Makedon sineması, toplumsal gerçeklikten uzaklaşmayan doğallığı ile yıllara sirayet ederek, aynı yapıtın defalarca izlenmesi başarısını sağlamaktadır. Toplumsal gerçeklik ile tesis edilen Makedon sineması dili, propaganda aracı olarak kullanımdan siyah dalga (iktidar karşıtı söylemlerin geliştirilmesi) olarak anılan akımlara, etnik ayrımcılık söylemlerinin yoğunlaştığı dönemlerden ideoloji temelli yönlendirmelere değin uzanan kavram karmaşası içerisinde, özgünlük, yaratıcılık, bağımsızlık ve emek yoğun üretim düsturundan uzaklaşmamıştır. Yugoslavya sinema ekolünün var olma çabasına dahil olan Makedon sineması yapıtlarını, gelecek nesiller adına ürettiklerini, insanlığın yaşam çabalarını sinema sanatı ile desteklerini, dogmalardan arınmış yaşamın renklerini insanlı̆̆ın hizmetine sunduklarını dile getirmektedirler. Gerçek ve nitelikli sanat yapılarının üretildiği dönemi ve siyasi kaygıları aşarak, her bir bireyin anlayabileceği yalın bir dil ile kurgulanması gerekliliği, insani, kültürel ve tarihi unsurları uhdesinde barındırma yetisi Makedon sineması yapıtlarında kendini göstermektedir.

\section{Kaynakça}

"Cinematheque of Macedonia", Production, http://www.maccinema.com, Erişim Tarihi: 01.07.2019.

"Filmska Banka", http://www.filmovi.com/de/film/, Erişim Tarihi: 01.07.2019.

"Po Povod 35 Godini Od Smrtta Na Milton Manaki”, Aktiven Ucesnik Vo Vnatre No Makedonskata Revolucionerna Organizacija, http://old.makedonskosonce.com/, Erişim Tarihi: 01.07.2019.

"Solunski Atentatori", https://www.imdb.com/, Erişim Tarihi: 01.07.2019.

"Vardar Film”, https://www.vardarfilm.mk/, Erişim Tarihi: 01.07.2019.

Braća Koja Su Kamerom Zabiljezila Zivot "Manaki - Etnologija i Vizualna Antropologija u Zitnici "Rupe", https://dubrovacki.slobodnadalmacija.hr/kultura, Erişim Tarihi: 01.07.2019. 
Dragana Garić, "Braća Manaki-Prve Filmadzije Na Balkanu, Filmom Protiv Zaborava", http://www.arte.rs/sr/umetnici/teoreticari/dragana_garic/, Erişim Tarihi: 01.07.2019.

Goulding, Daniel J., "Liberated Cinema: The Yugoslav Experience, 1945-2001", Indiana University Press, Bloomington\&Indiana Police, The Second Edition, 2002.

Igor Stardelov, "Balkanlar’n Işıı Ressamları Manaki Kardeşler”, Çeviren: Erol Mahmud, ESR Film Yapım ve Reklam Tanitım, 2014.

Manaki Braća, "Filmski Programi Arhiva", http://kinotuskanac.hr/director/braca-manaki?archived, Erişim Tarihi: 01.07.2019.

Roberta Januloskog, "Predstavljanje Monografije, Manaki Prica U Slikama o Janakiju İ Miltonu", https://www.kcb.org.rs/2018/o1/predstavljanje-monografije-manaki-prica-u-slikama-ojanakiju-i-miltonu-roberta-januloskog/, Erişim Tarihi: 01.07.2019.

Vidovdan (2018). "Braća Manaki İli Pokretne Slike Balkana", https://vidovdan.org/kultura/bracamanaki-ili-pokretne-slike-balkana/?script=lat. (Erişim Tarihi: 01.07.2019) 